\title{
175 石館守三，竹本常松：デギタリス葉の新强心性成分の研究
}

\author{
第 三 報 ${ }^{1)}$ デギタリス・ラナータ葉の研究
}

近年ずギタリス・ラナータ（Digitalis lanata Ehrh.）葉が配糖体の含量從つて其の効力に於て優秀なり と云はれデギタリス・プルプレア葉に替つて憘頭するに至つた。由來其の成分の化学的研究”るも活潑に 行はれ就中瑞西の A. Stoll, W. Kreis ${ }^{3}$ ) 氏等の原配糖体 (Genuine Glykoside) の研究即方新鮮葉を材 料とし酵素作用を防止しつつ行へる Digilanid A, B , C の分離に依つて此の方面の化学的研究も一段落

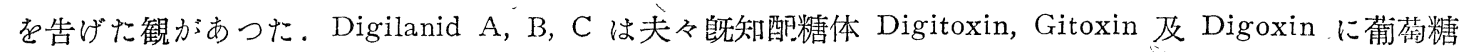
一分子, 醋酸一分子附加せるものである。而して葡萄糖は各配糖体の有する Digitoxose 分子の未端に 伉するであらう事が推定されたが醋酸基の結合位置は不明である。

Stoll 氏等は是等の原配糖体がヂギタリス・ラナータ葉（ギギタリス・プルプレアに就いても同樣）の 有する有效成分の全部を代表し得るものと見做し從來実驗藥理学並に臨床医芜に依つて訴へられた純粹 にされた配棣体はギギタリス葉の効力を悉くは代表し得ないと言ふ事実を解決し得けとしてるる4)。

然しデギタタス・プルプレア葉の場合と同樣ラナータ葉に於ける Stoll 氏等の原配糖体の研究もデギ タリスの「効力は毒力に本行する」と云ふ從來の說を前提とし毒力强きものを追求し以て足れりとして るる。

弦に於て著者等は本学藥理学敉室田村・小林及戸木田氏等と協力しプルプレア種の研究と同樣に之を 再檢討した。先づ新鮮ラナータ葉に就きStoll 氏等の研究を追試し所謂 Tannoid (Digilanid A, B, C の粗製混合物）を分離し藥理笑驗に供した。此の粗製 Tannoid はラナータ葉の有する勃力と毒力の大 部分を代表する事を認りたが觉精製するに從つて毒力は保持するも効力は著明に低下し Digilanid 型 物質の毒力及効力は Digitoxinの其等に近似するを認めた。一方瑞西バーゼル社製品 Digilanid に就き 行へる動物試驗の結果も毒力と効力との関係を考慮すれば Digitoxin 型化合物と大差なきを確認した。 さればラナータ葉に於てもプルプレア葉の楊合と同樣葉の効力代表する他の未知成分を期待せねばな らぬ。吾々はラナータ葉にもプルプレフ葉と同樣 Digicorin の存在を予想しラナータ乾燥葉末を材料と してプルプレア葉に於て施行せる方法に準拋して効力の代表物を追求した。其の結果ラナータ葉中にも 其の効力を代表する成分として Digicoringを分離し得た. Digicorin の含量はプルプレフ種より遙かに 多量であり (約 2 倍) 他の配糖体の含量と並行する事実は注目に值する。今ラナータ葉より得たるDigicorin の性壯とStoll 氏等の報告する Digilanid A, B 及 C の其れどの比較を次表に示す。

第 一 表

\begin{tabular}{|c|c|c|c|c|c|}
\hline 物 質 名 & 分子式 & 此旋光度 & 溶鮮度(水) & $\begin{array}{l}\text { 晝小有效量 } \\
0.2 \text {. }\end{array}$ & 毒力 $\mathrm{mg} / \mathrm{kg}$ 猫 \\
\hline デギコリン & $\mathrm{C}_{31} \mathrm{H}_{4 !} \mathrm{O}_{11}$ & {$[\alpha]_{D}^{31}=-14.4^{\circ}$} & $1: 1,200$ & 10-8(巨木田) & 4.9 （示田） \\
\hline デギラニドA & $\mathrm{C}_{49} \mathrm{H}_{76} \mathrm{O}_{19}$ & {$[\alpha]_{D}^{20}=+31.4^{\circ}$} & $1: 16,000$ & \multirow{3}{*}{$10^{-5}$ (戶木田) } & 0.38 (Rothlin) \\
\hline デギラニド B & $\mathrm{C}_{49} \mathrm{H}_{76} \mathrm{O}_{20}$ & {$[\alpha]_{D}^{20}=+36.7^{\circ}$} & - & & $0.40(" \prime)$ \\
\hline デギラニド C & $\mathrm{C}_{49} \mathrm{H}_{76} \mathrm{O}_{20}$ & $[\alpha]]_{D}^{20}=+33.5^{\circ}$ & $\begin{aligned} & 1:: 17,000 \\
& \sim 20,000\end{aligned}$ & & $0.281(" \prime)$ \\
\hline
\end{tabular}

第一表より明らかなる如くヂギュリンはヂギラニドより著しく分子量小で水にも遙かに易溶性であ

1) 第一報, 第二報 医学総筧第 1 卷 2 号 16,18 (炤和 20 年)

2) S. Smith: J. Chem. Soc. 508 (1930), C. Mannich: Arch. Pharm. 263, 453 (1930), 272, 5 (1934). P. Mohs: Chem. Ztg. 9, 99 (1936).

3) A. Stoll u. W. Kreis: Helv. Chim. Acta. 16, 1049 (1933), 17, 592 (1934), 18, 120 (1935).

4) A. Stoll - The cardiac glycosides, The Pharmaceutical Press, London (1937). 
る、其の毒力は 10 倍以上弱く其の効力は亦 $10^{3}$ 倍を示す。さればデギタリス・ラナータ葉に於ても既知 配糖体は主として毒性を代表する成分にして强心利尿作用の主体はギギュリンにありと称する事が出來 る。デギコリンの分離に位つて從來生葉と其の成分との間に橫たはる実驗藥理学上及臨床医学上の不明 の問題を大部分說明し得る所である。

著者等はヂギタリス・ラナータ乾燥葉末純アルュールを以て温時抽出してアルコールェキスとなし 之をアルコール含有の醋酸エチルに溶し其の 3 分の 2 を以て中幽アルえナを用ひクロマトグラフ処理に 附し残りの 3 分の 1 を以てデルカリ性アルえナを用ひて同樣クロマトグラフ処理に附した。中性アルえ ナを用ひたる場合は有效物質の大部分はアルそナ層を通過するに反しアルカリ性フルえナを用ひたる場 合はアルそナ層を通過する物質の量には大差なきも其の効力著しく微弱なることを認め從つてデギュリ ン製造の原料どしては不適当である。中性アルそナを使用して得たるクロマトグラフ滤液のエキスを再 び純醋酸エチルに溶解し活性炭を用ひて精製したる後重炭酸塩水溶液に移行せしめ再び鉱酸々性となし 醋酸エチルを以て有效物質を振取しエキスとなす。斯くして得たるエキスを乾燥エーテルを用ひて洗湺 すればデギュリンは無晶形粉末となる。本物質の得量は乾燥葉末の約 $1 / 5000$ なれど漧燥葉の烈ど全 効力を代表す。鉱酸に位る加水分解に徏り非糖体として融点 $175^{\circ} \mathrm{C}$ のギギュリぶニン(Digicorigenin)。 糖体としてヂギクロン酸 (Digicuronsäure) は一致する物質を得る。夫々プルプレア葉より得たる物質 と比較して碓認した。

アルそナ吸着物中よりはルテオリンの存在をベンゾアート。アセタートとして猚認し丈ギトキシンの 存在を鉱酸に依る扣水分解後生成せるギトキシグニンのベンゾアートとして証明した。又クロマトグラ フ通過物質中重炭酸盐溶液に不溶の物質中にギトキシンの存在を其のゲニンのベングフート及ギギトキ ソーゼの反應に依り証明し得た。其の他中性物質としてアルェールに難溶。水, エーテルに不溶, ピリ ヂンには易溶性の融点 $270 〜 280^{\circ} \mathrm{C}$ (分解) の無色無晶形物質を得ながか量なりしと藥理試驗の結果無 勃なりし䔄精查せず。本物質は Keller-Kiliani 反應界面オリーブ色, Legal 反應, Baljet 反應共に除 性, Liebermann 反應綠青色, 酸と加熱するも不変, 其のア七チル体は融点 $155 \sim 158^{\circ} \mathrm{C} \cdot$ の鱗片狀晶で ある

\section{實 驗之部}

靜岡縣御殿場町小宮山富太郎氏栽培にかかるデギタリス・ラナータ葉の風乾せる粗末を更に塩化カル シウム上に乾燥せるもの使用す。其の粉末蛙心絕対力测定法に依る最小有效量は $1: 10^{5} \sim 10^{6}$ 稀釈 溶液 $2 \mathrm{cc}$ である.（以下之を $W: 10^{-5} \sim 10^{-6} 2 \mathrm{cc}$ の如く記す。又蛙心靜止量测定に佧る毒力を $\mathrm{T} と$ 記す $)^{5)}$ 。この葉末 $250 \mathrm{~g}$ を約 21 の純酒精を以て 2 回温浸す。斯の如くして全量 $3 \mathrm{~kg}$ の葉末の浸液を 減圧下可及的低温にて約 1.51 に濃縮，一夜水室中に放置するに污綠色泥狀物を析出す。本沈澱は主と して微量の燐酸睢を混有せる塩化抈里である。之を濾別せるアルュール溶液を減圧蒸発乾固するに樹脂 樣エキス約 $160 \mathrm{~g}$ を得る。本エキスは $\mathrm{W}: 10^{-6} 2 \mathrm{cc}, \mathrm{T}: 10^{-4} 1 \mathrm{cc}$ なり。此のエキスを $10 \%$ アルュ

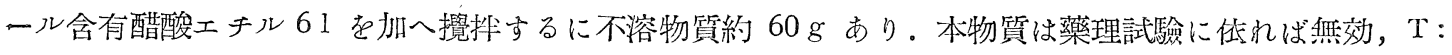

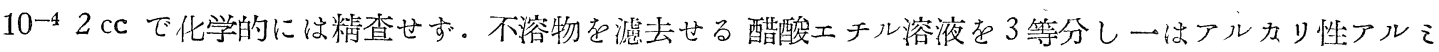
ナ，他は中性アルえナを用ひてクロマトグラフ処理に附す。

\section{（1）中性买昛ミナを使用せる場合}

昭和電工会社製アルえナを稀塩酸にて洗湺し後加熱し殆と中性反應を呈せるものを使用す。直径 $46 \mathrm{~cm}$ 高さ $15 \mathrm{~cm}$ の層とし先づアルそナ層をアルユール含有醋酸エチルを以て洗滥せる後上記エキス 溶液 21 約 2 時間 30 分を要して流下せしむ。後更に同溶媒 $400 \mathrm{cc}$ を以て展開せしむ。全操作は炭酸

5) 田村·小林・戶未田：日本藥理学雜誌 第 40 卷 314 頁参照 
ガス氣流中にて施行し空氣との接触を避くるに努めた。斯くしてアルえナ層通過滤液を集め減圧蒸発す れば暗綠色樹脂梯物質 $15 \mathrm{~g}$ を得。 2 回の得量は合せ $30 \mathrm{~g}$ 。本品は $\mathrm{W}: 10^{-7} 、 2 \mathrm{cc}, \mathrm{T}: 10^{-4} 2 \mathrm{cc}$ 。又本 品の 1 万倍氷醋酸溶液につき Keller-Kiliani 反應を檢ずるにギトキシグニンの赤紫色 (硫酸層) 及デギ トキソーゼの青色 (水醋酸層) を認む。

\section{（ロ）アルカリ性アルミナを使用せる場合}

昭和電工会社製フルそナ $\left(\mathrm{Na}_{2} \mathrm{O} 0.22 \%\right.$ 含有）を用ひ前記(イ)同樣処理せるにクロマトグラム通過物質 として同しく樹脂樣物質約 $15 \mathrm{~g}$ を得. Keller-Kiliani 反應は(イ)の場合と同樣なれぞも効力著しく劣り

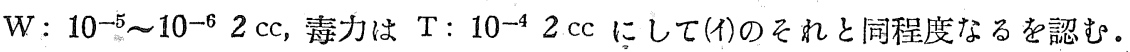

\section{デギコリンの分離}

前記(イ)の方法に佂りて得たるエキス $30 \mathrm{~g}$ を純醋酸エチル約 1 に溶し小量の脫色炭を以て脫色した る綠色澄明溶液を $5 \%$ 重炭酸ソーダ水溶液各 $500 \mathrm{cc}$ をて 3 回良く振盪す。此の重炭酸ソーダ溶液 （PH 8.3 附近）党冷却しつつ塩酸にて强酸性となし食塩にて塩析しつつ醋酸エチル各 $500 \mathrm{cc}$ を以て 3 回 抽出す。醋酸エチル溶液を合して飽和食塩水を以て洗棌後芒硝にて乾燥し炭酸ガス氣流中にて減圧乾固 す。之を更に純酒精 $30 \mathrm{cc}$ に溶解し脫色炭にて脫色せる後溶媒を減王溜去すれば帶黃色の樹脂樣物質約

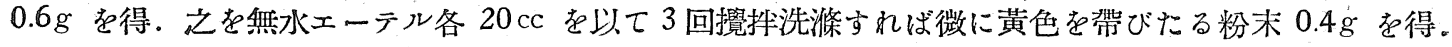
本品は先にデギタリス・プルプレフ葉より分離せるデギュリンと其の性狀一致する。 $\mathrm{W}: 10^{-9} 2 \mathrm{cc}, \mathrm{T}$ : $10^{-4} 2 \sim 4 \mathrm{cc}, \alpha=0.26^{\circ}$ (C=1.80 純ノコール, $1 \mathrm{dm}$-管). 從つて $[\alpha]_{\mathrm{D}}^{31}=14.4^{\circ}$ 。

デギコリン $0.385 \mathrm{~g}$ を採り之をフルコール性塩酸を以て簽化すれば非糖体デギコリグニン $0.220 \mathrm{~g}$ 得。其の得量は理論值の $87.8 \%$ に相当す。本デギュリダニンは融点 $175^{\circ} \mathrm{C}$ の細釬狀晶より成る球晶 にしてプルプレフ葉より得たるものと混融して降下を認めす。又其の他の性狀も悉くプルプレフ葉のそ れに一致す。 $\mathrm{W}: 10^{-8} \sim 10^{-9} 2 \mathrm{cc}, \mathrm{T}: 10^{-4} 0.5 \mathrm{c}$.

一方糖体は組成 $\mathrm{C}_{6} \mathrm{H}_{9} \mathrm{O}_{6} \mathrm{Ag}$ に一致する銀塩を生成し又其の $\mathrm{p}$ ーニトフエニールヒドラッオンヒドラ

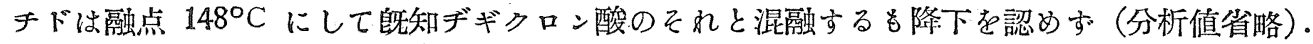

東京帝國大学医学部藥学科分析学敉室（昭和 20 年 4 月 12 日受理） 


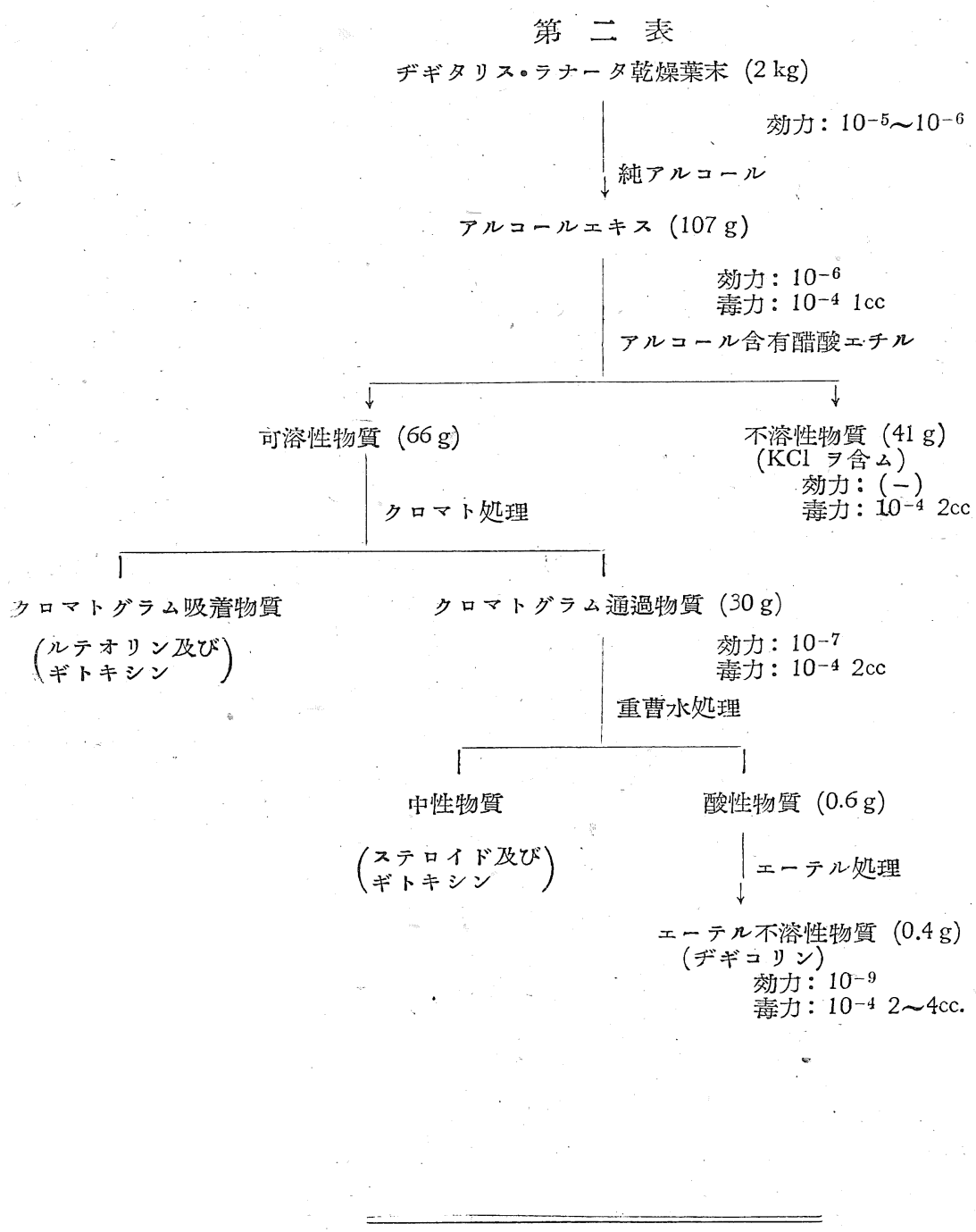

